Original Research Paper

\title{
Immobilized Whole Cell System with Methyl Parathion- Degrading Activity for Organophosphate Insecticide Detection
}

\author{
Chadaporn Pootawee, Witsanu Senbua and Jesdawan Wichitwechkarn \\ Department of Biotechnology, Faculty of Engineering and Industrial Technology, Silpakorn University, \\ Nakhon Pathom 73000, Thailand
}

\author{
Article history \\ Received: 10-07-2018 \\ Revised: 01-09-2018 \\ Accepted: 17-09-2018 \\ Corresponding Author: \\ Jesdawan Wichitwechkarn \\ Department of Biotechnology, \\ Faculty of Engineering and \\ Industrial Technology, \\ Silpakorn University, \\ Nakhon Pathom 73000, \\ Thailand \\ Tel./Fax +66 34219360 \\ Email: wjesdawan@gmail.com
}

\section{Introduction}

Organophosphate (OP) compounds, a group of neurotoxic substances, have been extensively used as pesticides and insecticides in agriculture worldwide, especially in many developing countries. These substances have been used as chemical warfare agents as well. OP insecticides exert their toxicity by inhibiting acetylcholinesterase (AChE) which hydrolyses a neurotransmitter acetylcholine, resulting in its accumulation in the synapses of the nervous system (Abou-Donia, 2003). This causes a wide range of OP toxicity symptoms involving nervous system disorder, teratogenicity, carcinogenicity, impairment of the reproductive system and detrimental impact on biological macromolecules (Ahmadizad Firozjaei et al., 2015; Kumar et al., 2016). The symptoms can be dizziness, headache, nausea, vomiting, fatigue, blurred vision, excessive salivation, confusion, depression, emotional lability, memory loss, convulsion, anoxia,

\begin{abstract}
As the result of the extensive use and high contamination of organophosphate (OP) insecticides in agricultural products and the especially in developing countries, a simple and convenient the recombinant clone BpGP carrying methyl parathion (MP) degrading $m p d B$, gene originating from MP-degrading Burkholderia cepacia and possessing MP-degrading activity were immobilized onto the polystyrene by cross-linking with glutaraldehyde. The immobilized cells were used as a -component for spectrophotometric detection of OP compounds, with count a reses rectict attached to the well surface. The system was most stable at $25^{\circ} \mathrm{C}$ and could be used to detect MP repetitively up to 46 rounds, although it was still active at about $45 \%$ until round 100 . For MP analysis, the linear range of on spiked and real samples were also performed and the results revealed high detection efficiency. This immobilized cell microtiter plate system has a great potential to be utilized as an alternative for OP detection and screening with the advantages of simplicity, stability, ease and convenience
\end{abstract} Keywords: Cell Immobilization, Methyl Parathion Detection, Methyl Parathion Hydrolase, MPH-GST, Organophosphate cardiac arrhythmias and respiratory failure which can eventually lead to death (Maxwell et al., 2006; Ahmadizad Firozjaei et al., 2015; Kumar et al., 2016). FAO/WHO have set maximum residue limits (MRLs) for pesticides in Codex Alimentarius International Food Standard (FAO/WHO, 2018). Due to high threats to human health and the ecosystem resulting from OP contamination in food products and the environment, sensing devices that are simple, rapid and sensitive are required for effective control and monitoring of these substances.

OP enzyme biosensors were developed using AChE (Roger et al., 1991; Danzer and Schwedt, 1996; Andres et al., 1997; Palchetti et al., 1997; Andreou and Clonis, 2002; Gong et al., 2009; Raghu et al., 2012; Xue et al., 2012; Zheng et al., 2015). However, the inhibition-based $\mathrm{AChE}$ biosensors relying on the indirect detection has a disadvantage of poor selectivity since AChE can also be inhibited by many other neurotoxins. Moreover, because of its irreversible response, 
this type of biosensor is not readily reusable. Other approaches for direct detection of OP compounds were enzyme biosensors using organophosphate hydrolase (OPH) (Mulchandani et al., 1999; Deo et al., 2005; Ji et al., 2005; Simonian et al., 2005; Laothanachareon et al., 2008; Lee et al., 2010; Tang et al., 2014) and methyl parathion hydrolase (MPH) (Ekkhuntham et al., 2010; Chen et al., 2011; Zhao et al., 2013; Liu et al., 2014; Ye et al., 2016), based on optical, conductometer and electrochemical methods. These approaches, though yielding good sensitivities and very low detection limits, are complicated, involving time-consuming and laborintensive purification of the enzyme and perplexed assembly of many types of expensive materials such as multiwall carbon nanotubes and gold nanoparticles. Other studies were done on whole cell detection systems. Kumar and D'Souza (2010) fabricated an optical microbial biosensor for MP detection using whole cells of Flavobacterium sp. immobilized by adsorption on glass fiber filter as a bio-component. Shing et al. (2013) developed a whole cell biosensor by direct entrapment of a cyanobacterium, Anabaena torulosa, onto a cellulose membrane for heavy metal and pesticide detection.

In our laboratory, MP-degrading bacteria were isolated from soil in Thailand and were identified as Burkholderia cepacia (Keprasertsup et al., 2001). The MP-degrading enzyme, MPH, was isolated and purified to homogeneity (Ekkhuntham et al., 2012) and the gene coding for MPH, $m p d B$, was cloned in Escherichia coli, yielding the recombinant clone BpGP. This clone contained MPH activity, capable of degrading MP and other phenyl-substituted OP substances to a yellow product, $p$-nitrophenol (PNP) which can be easily detected via spectrophotometry at the wavelength of 410 $\mathrm{nm}$. Here we report the development of immobilized whole cell system from our clone BpGP for the detection of OP insecticides, using MP as a representative. Its use on spiked and real samples such as agricultural products and tap water were also investigated. This system is a simple, easy and cost-effective means for OP detection which is needed in developing countries where OP insecticides are widely used and there are a lot of residues found in both agricultural products and the environment. This detection system with simple design, low cost and convenience for use is more practically applicable in field work, especially for the screening of OP contamination in food products, soil and water sources, which can provide an easy precaution against these toxic compounds.

\section{Materials and Methods}

\section{Bacteria and the Construction of Clone BpGP}

The bacterium Burkholderia cepacia capable of degrading MP was previously isolated from soil in the western part of Thailand (Keprasertsup et al., 2001). The MPH involved in the hydrolysis of MP to PNP was purified and its N-terminal amino acid sequence was determined (Ekkhuntham et al., 2012). Its gene, mpdB, was cloned into an expression plasmid pGEX 6P-1 (GE Healthcare Life Sciences, USA), an expression vector designed for production of a fusion protein with glutathione- $S$-transferase (GST) at the N-terminus. This was done by extracting the recombinant plasmid DNA (pGEX 4T-2 harboring $m p d B$ gene) from clone BpGT in which $m p d B$ gene had previously been cloned (Ekkhuntham et al., 2012) and cutting the plasmid DNA with BamHI and XhoI. The purified BamHI-XhoI DNA fragment harboring $m p d B$ gene was then ligated to the plasmid pGEX $6 \mathrm{P}-1$ and the recombinant plasmid was transformed into E. coli BL21, yielding clone BpGP. The $m p d B$ gene was expressed in $E$. coli as MPH that fused with GST (MPH-GST). The cells of the clone were grown in LB medium with $100 \mu \mathrm{g} / \mathrm{mL}$ of ampicillin at $37^{\circ} \mathrm{C}$ with shaking at $200 \mathrm{rpm}$ until $\mathrm{OD}_{600}$ of 0.5 was reached and then were induced by $1 \mathrm{mM}$ IPTG in the presence of $0.5 \mathrm{mM}$ $\mathrm{CoCl}_{2}$. The culture was allowed to grow further at $18^{\circ} \mathrm{C}$ for $6 \mathrm{~h}$ at which the cells were in the logarithmic phase (Ekkhuntham et al., 2012). The cells were centrifuged at $8,000 \mathrm{xg}$ at $4^{\circ} \mathrm{C}$ for $20 \mathrm{~min}$. The pellet was washed twice with $50 \mathrm{mM}$ phosphate buffer saline (PBS), $\mathrm{pH} 8.0$ and resuspended in the buffer. The cells were tested for MP degradation activity using MPH microtiter plate assay and/or spectroscopic measurement at $410 \mathrm{~nm}$.

\section{Cell Immobilization}

Cells from clone BpGP were immobilized onto the well surface of 96-well polystyrene microtiter plates, using adsorption method, followed by cross-linking with glutaraldehyde (Kumar and D'Souza, 2010; 2011). Briefly, cells from the culture of clone BpGP were harvested, washed and resuspended in $50 \mathrm{mM}$ PBS, $\mathrm{pH}$ 8.0. The cell suspension was added to the center of each well. The plates were kept at $4^{\circ} \mathrm{C}$ until the cells were dried. The volume of the cell suspension was varied as $10,20,30,40$ and $50 \mu \mathrm{L}$. Glutaraldehyde of varying percentages $(0.2,0.5,1,2$ and $5 \% \mathrm{v} / \mathrm{v})$ was separately added to each well at different volumes $(8,10$ and 12 $\mu \mathrm{L})$. The plates were left at room temperature for $3.5 \mathrm{~h}$. The wells were then gently washed with $50 \mathrm{mM}$ PBS, $\mathrm{pH} 8.0$ and kept at $4^{\circ} \mathrm{C}$ until use.

Electron microscopic analysis of the immobilized cells on the well surface was performed using scanning electron microscope (SEM) (Hitachi TM3000, Japan). The wells were cut to the height of $2 \mathrm{~mm}$ and after cell immobilization was done, the well surface was coated with gold particles before viewed under SEM. The magnifications used were $1,000 \mathrm{x}$ and $10,000 \mathrm{x}$. Immobilized cells were counted, using total plate count technique, by washing the wells with $50 \mathrm{mM}$ phosphate 
buffer, $\mathrm{pH} 8.0$ and the washed-out cell suspension were diluted and spread onto LB plates containing $100 \mu \mathrm{g} / \mathrm{mL}$ ampicillin. The plates were incubated overnight at $37^{\circ} \mathrm{C}$ and the number of cells were determined as CFU/mL.

Temperature Stability and Reusability of the Immobilized Cells for MP Detection

To determine the effect of temperature on the stability of the immobilized cell system for MP detection, $50 \mu \mathrm{g} / \mathrm{mL}$ of MP was added to the wells and the reactions were allowed to occur at different temperatures $\left(4,25,37\right.$ and $\left.50^{\circ} \mathrm{C}\right) . \mathrm{OD}_{410}$ was measured after $5 \mathrm{~min}$ incubation every day for 30 days by microplate reader (Tecan, Switzerland). For the test on reusability, $50 \mu \mathrm{g} / \mathrm{mL}$ of MP was added to the wells at each round of detection. After $5 \mathrm{~min}$ incubation at $25^{\circ} \mathrm{C}$, $\mathrm{OD}_{410}$ was measured. Cell suspensions were gently removed after each round of reaction and the wells were washed with $50 \mathrm{mM}$ PBS, $\mathrm{pH} 8.0$, before starting the new round until the total of 100 rounds. MP concentrations were derived using linear calibration curve. All reactions were done in triplicate.

\section{Effect of MP Concentration on Spectrophotometric Measurement}

For the effect of MP concentration on $\mathrm{OD}_{410}$, varying concentrations of MP $(2-250 \mu \mathrm{g} / \mathrm{mL})$ were added to different wells and the reactions were allowed to occur for $5 \mathrm{~min}$ before $\mathrm{OD}_{410}$ was measured. The tests were performed in triplicate. The detection limit and linear range for MP detection were determined as previously described (Kumar and D'Souza, 2010).

\section{Test on Spiked and Real (Non-Spiked) Samples}

Samples from agricultural products such as green grapes, basil leaves, Chinese kale, asparagus and agasta were obtained from fresh markets. They were washed with distilled water and chopped into small pieces. PBS, pH $8.0(50 \mathrm{mM})$ was added at the ratio of $10 \mathrm{~mL}$ per $5 \mathrm{~g}$ samples. The samples were stirred for $1 \mathrm{~h}$, filtered, centrifuged at $10,000 \mathrm{xg}$ and the precipitates discarded. For spiked samples, an appropriately diluted solution of MP in PBS, pH 8.0 was spiked into agricultural and tap water samples to the final concentration of $50 \mathrm{ppm}$ and $200 \mu \mathrm{l}$ of each sample was transferred to each well containing immobilized cells. The spiked samples were assayed for MP using the immobilized cell system by measuring $\mathrm{OD}_{410}$ for PNP production and the MP concentrations were derived from linear calibration curve. The percentages of MP recovery were determined. Real samples were analyzed for MP residues using the same procedure as that of spiked samples. All tests were performed in triplicate.

\section{Results}

\section{Clone BpGP and Cell Immobilization}

The cells used for immobilization were from the clone BpGP containing $m p d B$ gene cloned into plasmid pGEX 6P-1 and transformed into E. coli BL21. The $m p d B$ gene expressed well in $E$. coli, yielding functional MPH in the form of MPH-GST fusion protein and hence rendering the clone to possess the MP-degrading activity. MP degradation reaction is shown in Fig. 1.<smiles>COP(=S)(OC)Oc1ccc([N+](=O)[O-])cc1</smiles>

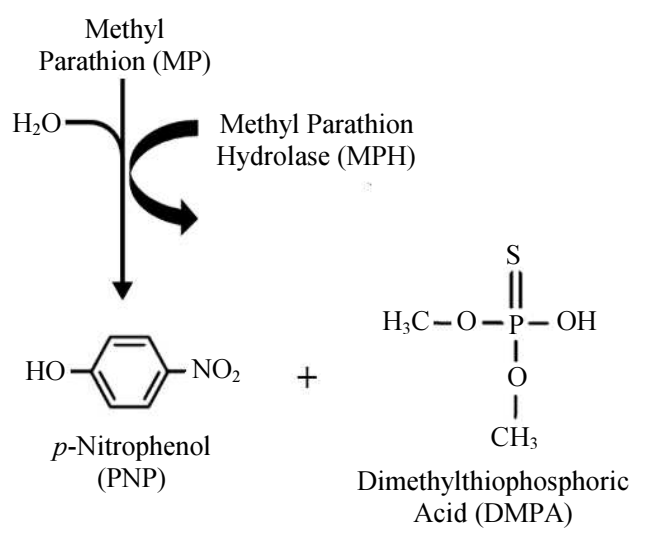

Fig. 1: MP degradation reaction by MPH

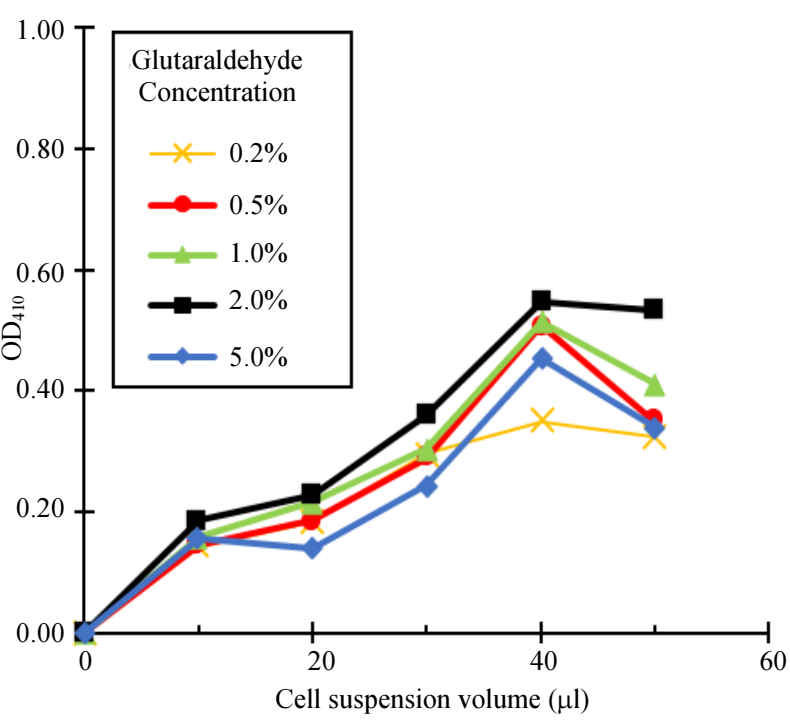

Fig. 2: Optimization of cell loading and glutaraldehyde concentration for immobilization 
The cells from clone BpGP were immobilized onto the polystyrene surface of the microtiter plate wells by adsorption, followed by cross-linking with the aid of glutaraldehyde. Cell suspension volume of $40 \mu \mathrm{L}$, glutaraldehyde concentration of $2 \%$ and glutaraldehyde volume of $10 \mu \mathrm{L}$ yielded highest $\mathrm{OD}_{410}$ and were optimal conditions for cell immobilization (Fig. 2 and 3).

When the cells were immobilized under optimal conditions, only a negligible number of cells were washed out during washing. The number of cells being washed out was only $930 \mathrm{CFU} / \mathrm{mL}$ as compared to $1.1 \times 10^{9} \mathrm{CFU} / \mathrm{mL}$ of the start cell number used for the immobilization. From SEM analysis, highly dense bacteria were seen attached to the well surface (Fig. 4A) while only debris from well cutting was found on empty wells (Fig. 4C). When viewed at 10 times higher magnification $(10,000 x)$ rod-shaped bacteria characteristic of E. coli were clearly revealed (Fig. 4B).

\section{Temperature Stability and Reusability}

This immobilized whole cell detection system was tested for the temperature stability. The system was most stable and attained highest activity at $25^{\circ} \mathrm{C}$. It can be seen from Fig. 5 that at $25^{\circ} \mathrm{C}$ the relative activity increased gradually from day 4-11 to about twice as much and dropped to about $60 \%$ on day 18 , after which it remained constant throughout the experiment. This increased activity peak was observed only at $25^{\circ} \mathrm{C}$. This is an advantage of the system that permits its practical use at around room temperature. The temperature of $4^{\circ} \mathrm{C}$ was the second most suitable for the stability, while at $37^{\circ} \mathrm{C}$ and $50^{\circ} \mathrm{C}$, the relative activities rapidly dropped to the final percentages of about 50 and 18 , respectively.
When determining the reusability for MP detection, it appeared that the system could be reused for 46 rounds and was still active at about $45 \%$ until round 100 . As illustrated in Fig. 6, the relative activity remained at approximately $70 \%-100 \%$ for the first 22 rounds and then decreased to about $40 \%-60 \%$ until round 46 . From round 46 on, the relative activity dropped to approximately $42 \%-45 \%$ and remained constant throughout the experiment.

\section{Effect of MP Concentration on Spectrophotometric Measurement}

The effect of MP concentration on the immobilized cell detection system was also investigated by measuring $\mathrm{OD}_{410}$ at varying concentrations of MP $(2-250 \mu \mathrm{g} / \mathrm{mL})$. As illustrated in Fig. 7, the linear range of the system was $2-200 \mu \mathrm{g} / \mathrm{mL}$ and the detection limit was $2 \mu \mathrm{g} / \mathrm{mL}$.

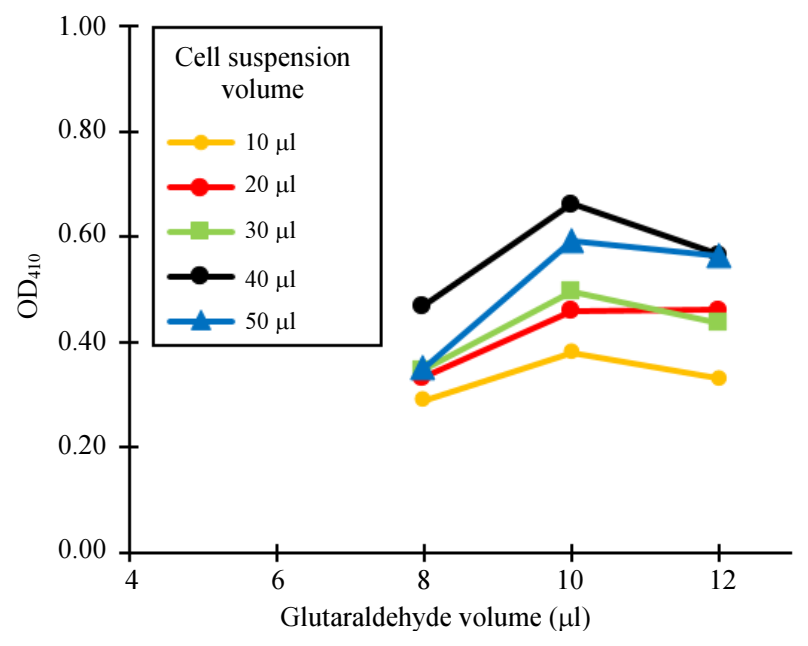

Fig. 3: Optimization of glutaraldehyde volume and cell suspension volume for immobilization

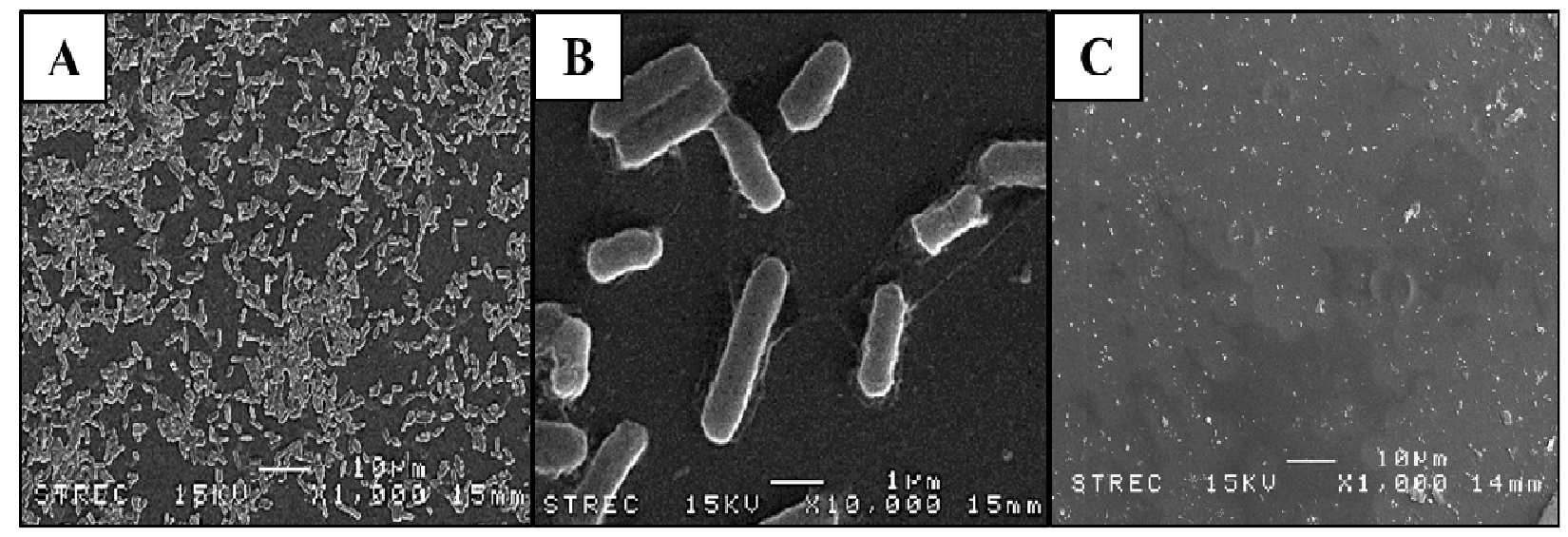

Fig. 4: Scanning electron micrographs of well surfaces with (A and B) and without (C) immobilized cells. A and C were performed at 1,000x; B was performed at 10,000x 


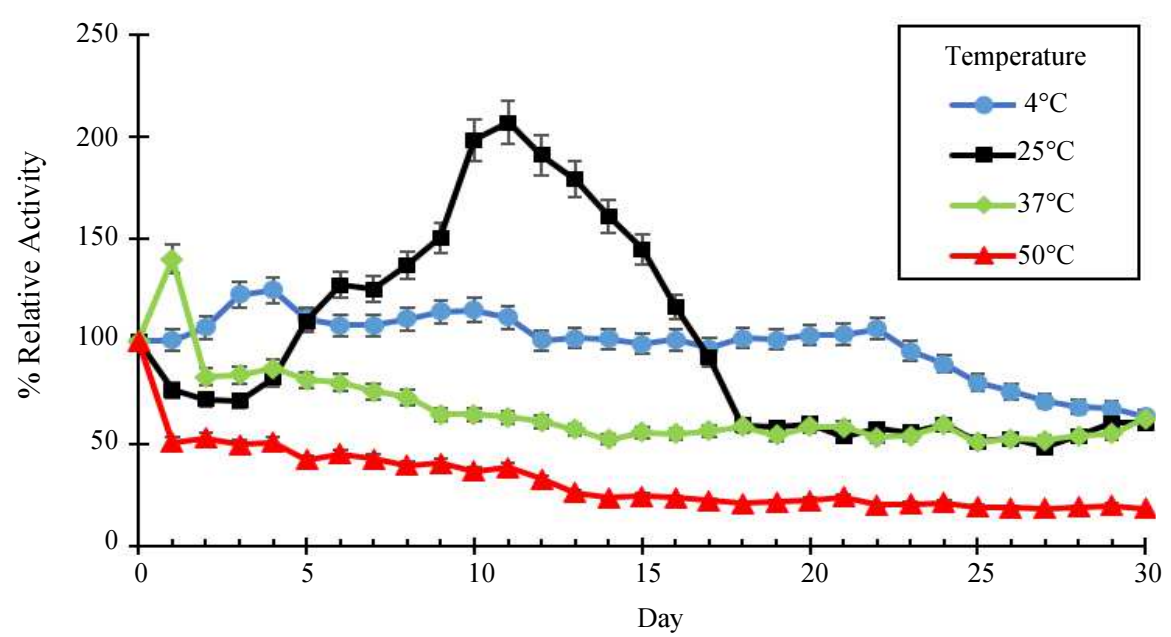

Fig. 5: Effect of temperature on stability of the immobilized cell for the detection of MP

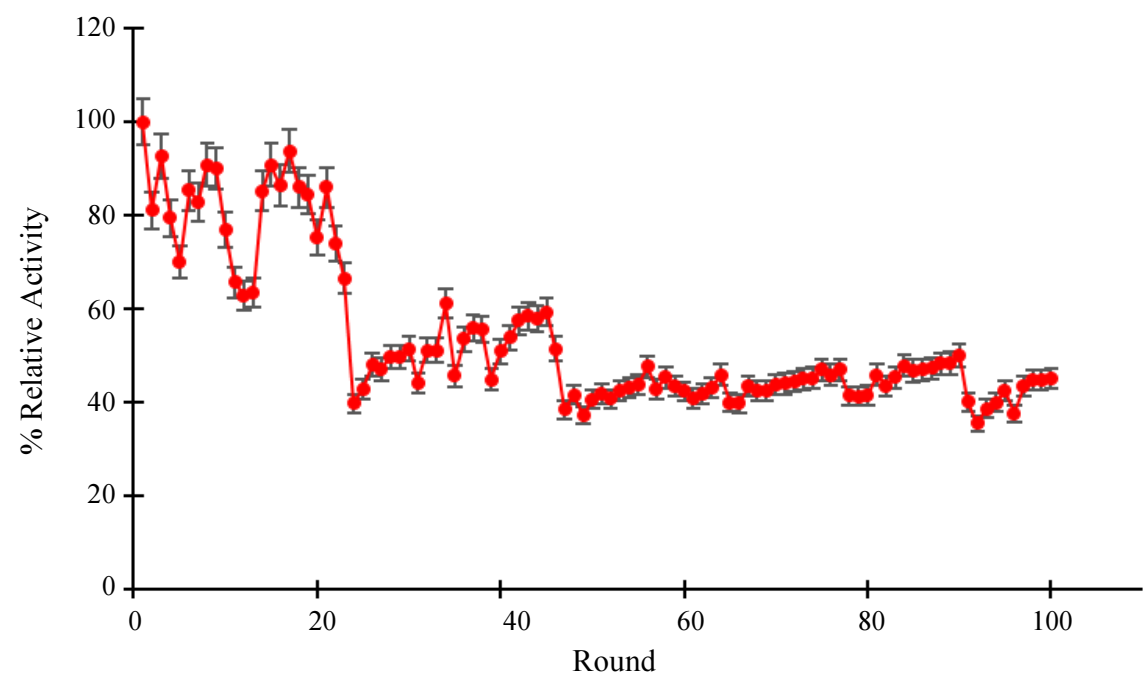

Fig. 6: Reusability of the immobilized cells for MP detection

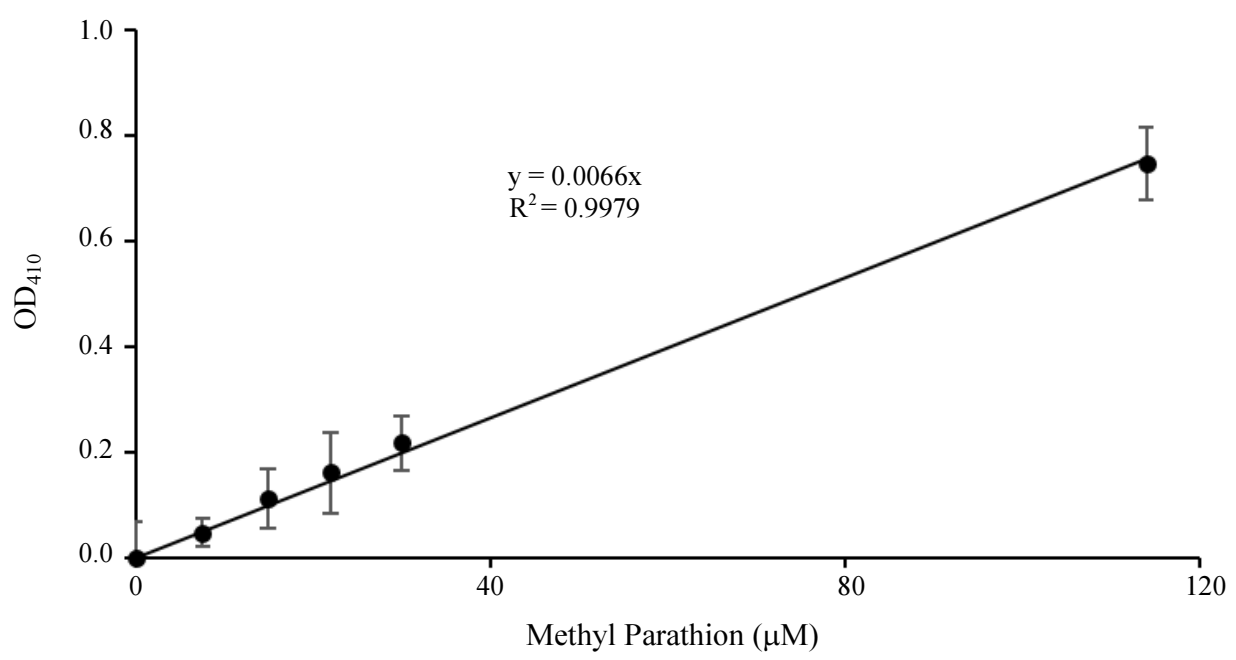

Fig. 7: Effect of MP concentration on $\mathrm{OD}_{410}$ value 
Table 1: Percentages of MP recovery by the immobilized cell detection system on $50 \mathrm{ppm}$ MP-spiked samples

\begin{tabular}{ll}
\hline MP Spiked-Samples & MP Recovery (\%) \\
\hline Tap water & 95.1 \\
Green grapes & 99.5 \\
Basil leaves & 96.7 \\
Chinese kale & 89.8 \\
\hline
\end{tabular}

Table 2: Concentrations of MP in real (non-spiked) samples detected by the whole cell sensing system

\begin{tabular}{lc}
\hline Real Samples & MP Concentration $(\mu \mathrm{g} / \mathrm{mL})$ \\
\hline Tap water & 1.50 \\
Green grapes & 8.15 \\
Basil leaves & 7.82 \\
Chinese kale & 7.31 \\
Asparagus & 22.00 \\
Agasta & 25.00 \\
\hline
\end{tabular}

\section{Test on Spiked and Real (Non-Spiked) Samples}

The immobilized cell system was tested for MP detection in spiked samples. The agricultural samples selected were fruits and vegetables such as green grapes, basil leaves and Chinese kale. These samples, together with tap water, were spiked with $50 \mathrm{ppm}$ MP and were tested for MP detection with the immobilized cell system. The percentages of MP recovery were as high as 89.899.5, reflecting high detection efficiency of the system (Table 1). The immobilized cell system was also tested for MP detection in real samples, which were agricultural samples and tap water without MP spiking. It was capable of detecting MP in real samples as shown in Table 2.

\section{Discussion}

Since neurotoxic OP insecticides are widely utilized and their residues are found to contaminate agricultural products like fruits and vegetables, water and soil sources, especially in agricultural areas of developing countries, a simple, easy, inexpensive and convenient way for OP insecticide detection is highly needed. Here, whole cells from clone BpGP, containing $m p d B$ gene and possessing MP-degrading activity, were studied for such a purpose. The cells were immobilized onto the polystyrene surface of the wells of microtiter plates. Various methods for cell immobilization were discussed (Phillips and Poon, 1988). Here, the immobilization performed by adsorption, followed by cross-linking using glutaraldehyde was successful, with most of the cells remaining attached to the surface after washing. This immobilized cell system was studied for its application as a sensing device on OP detection, using MP as a representative. With the reusability of 46 rounds and up to 100 rounds with about $45 \%$ activity and temperature stability at $25^{\circ} \mathrm{C}$, as well as its good linear range and low detection limit, the system has a high potential for practical application in the detection and screening of OP contamination in agricultural products and the environment. Considering that this sensing device was a simple one with the use of minimum materials for its assembly, the detection limit was good enough for its use on OP screening. The detection limit for OP substances can be further improved by using immobilized enzyme system or by connecting the whole cell system to a transducer. High percentages of MP recoveries from the system tests on agricultural samples and water spiked with known amount of MP have confirmed its practicality. This immobilized whole cell system has advantages of simplicity, stability, ease and convenience for assembly and use, and costeffectiveness. Although other systems such as recently made electrochemical biosensors might give extremely low detection limits, they have to be fabricated at the expense of simplicity and low cost, which is more desirable in certain circumstances, especially in developing countries. Most of these systems involved the use of numerous specific materials such as nanoparticles or nanotubes, with many steps of complicated assembly procedures. Other systems were designed as simple sensing devices for OP detection. Anh et al. (2011) used a very simple colorimetric assay for the determination of MP. Kumar and D'Souza (2010) designed an immobilized whole cell system from whole cells of Sphingomonas sp. on microplates and studied its use as a reusable bio-component for an MP optical microbial biosensor. The detection system utilizing microtiter plates also has an advantage of capability to detect multiple numbers of samples in a single platform. Another advantage of microbial biosensors over enzyme biosensors is that the enzyme activity of the cells can produce specific and sensitive responses to the substrates without undergoing costly, time-consuming and laborintensive process of enzyme isolation and purification (Lei et al., 2006; Su et al., 2011; Dai and Choi, 2013). Microbial biosensors have been reviewed on various interesting aspects (Ding et al., 2008; Zhang and Keasling, 2011; Dhanekar and Jain, 2013). Our immobilized cell system on microtiter plates presented here could detect MP efficiently, with stability, reusability, low detection limit and good linear range and hence, this system can be an alternative means for simple, rapid and convenient screening of OP contamination. From our previous work, it was shown that the MPH activity derived from the expression of the cloned $m p d B$ gene was capable of efficiently hydrolyzing numerous OP insecticides other than MP (Ekkhuntham et al., 2012). Moreover, many nerve agents that are used as chemical warfare agents such as sarin, soman, tabun and VX are also OP substances (Compton, 1988; Watson et al., 2009). The ability to degrade these nerve agents by variants of an organophosphate-degrading enzyme has been reported (Dawson et al., 2008). So, this immobilized cell detection system with MP-degrading activity may have wider applications than expected. 


\section{Conclusion}

In this study, the use of immobilized whole cells from recombinant clone BpGP possessing MP-degrading activity on the polystyrene surface of $96-$ well microtiter plates as an OP sensing device was described. Cell immobilization was successfully performed by adsorption followed by cross-linking with glutaraldehyde. The system was studied for its detection of OP insecticides, with MP as a representative, demonstrating its good performing characteristics. MP detection in agricultural and water samples spiked with MP showed high percentages of recovery. This system was also capable of detecting MP in real samples. Thus, this immobilized cell bio-component system using 96-well microtiter plates has a great potential as a selective means for practical detection of OP substances with simplicity, both in its design and its use, reusability, stability, low cost and ability to detect multiple samples simultaneously, while being able to detect MP at low detection limit and good linear range. These qualities are more desirable in certain circumstances like fast screening for OP contamination in food and water, especially in developing countries where tremendous amounts of OP insecticides are used and an urgent elimination of their threats to humans is strongly needed.

\section{Acknowledgement}

This research was supported by a grant from Graduate School and the government budget through the Department of Biotechnology, Faculty of Engineering and Industrial Technology, Silpakorn University, and partly by the grant from Thailand Research Fund. The authors thank Dr. Jhirat Mearnchu for helpful suggestions. We also thank Miss Tipaporn Subsomboon for technical support and Mr. Nutthawut Pheungphasutadol for helps on artwork and figure preparation for the manuscript.

\section{Funding Information}

This research was supported by a grant from Graduate School and the government budget through the Department of Biotechnology, Faculty of Engineering and Industrial Technology, Silpakorn University, and partly by the grant from Thailand Research Fund.

\section{Author's Contributions}

Chadaporn Pootawee: Worked, as a Master's student, on cell immobilization, fabrication of immobilized cell biosensing device, SEM and plate count analysis, temperature stability and reusability of the system.

Witsanu Senbua: Worked as a Ph.D. student, on the effect of MP concentration on spectrophotometric measurement and the tests for MP detection in spiked and real samples using the immobilized cell detection system.
Jesdawan Wichitwechkarn: Was in charge, as a principal investigator, of the administration, guidance and supervision of the research, as well as the preparation of the manuscript. All authors have read and approved the final manuscript.

\section{Ethics}

The authors declare that they have no conflict of interest in the publication.

\section{References}

Abou-Donia, M.B., 2003. Organophosphorus esterinduced chronic neurotoxicity. Archives Environmental Health, 58: 484-497. DOI:10.3200/AEOH.58.8.484-497

Ahmadizad Firozjaei, S.A., A.M. Latifi, S. Khodi, S. Abolmaali and A. Choopani, 2015. A Review on biodegradation of toxic organophosphate compounds. J. Applied Biotechnology Reports, 2: 215-224.

Andreou, V.G. and Y.D. Clonis, 2002. A portable fiberoptic pesticide biosensor based on immobilized cholinesterase and sol-gel entrapped bromcresol purple for in-field use. Biosensors Bioelectronics, 17: 61-69. DOI: 10.1016/S0956-63(01)00261-5

Andres, R.T. and R. Narayanaswamy, 1997. Fibre-optic biosensor based on covalently immobilized acetylcholinesterase and thymol blue. Talanta, 44: 1335-1352. DOI: 10.1016/S0039-9140(96)02071-1

Anh, D.H., K. Cheunrungsikul, J. Wichitwechkarn and W. Surareungchai, 2011. A colorimetric assay for determination of methyl parathion using recombinant methyl parathion hydrolase. Biotechnology J., 6: 565-571.

DOI: $10.1002 /$ biot.201000348

Chen, S., J. Huang, D. Du, J. Li and H. Tu et al., 2011. Methyl parathion hydrolase based nanocomposite biosensors for highly sensitive and selective determination of methyl parathion. Biosensors Bioelectronics, 26: 4320-4325. DOI:10.1016/j.bios.2011.04.025

Compton, J.A.F., 1988. Military Chemical and Biological Agents: Chemical and Toxicological Properties. Telford Press, Caldwell, New Jersey. ISBN: 0936923113, pp: 458.

Dai, C. and S. Choi, 2013. Technology and applications of microbial biosensor. Open J. Applied Biosensor, 2: 83-93. DOI: 10.4236/ojab.2013.23011

Danzer, T. and G. Schwedt, 1996. Chemometric methods for the development of a biosensor system and the evaluation of inhibition studies with solutions and mixtures of pesticides and heavy metals Partl. Development of an enzyme electrodes system for pesticide and heavy metal screening using selected chemometric methods. Analytica Chimica Acta, 318: 275-286. DOI: 10.1016/0003-2670(95)00460-2 
Dawson, R.M., S. Pantelidis, H.R. Rose and S.E. Kotsonis, 2008. Degradation of nerve agents by an organophosphate-degrading agent (OpdA). J. Hazardous Materials, 157: 308-314. DOI: 10.1016/j.jhazmat.2007.12.099

Deo, R.P., J. Wang, I. Block, A. Mulchandani and K.A. Joshi et al., 2005. Determination of organophosphate pesticides at a carbon nanotube/organophosphorus hydrolase electrochemical biosensor. Analytica Chimica Acta, 530: 185-189.

DOI: $10.1016 /$ j.aca.2004.09.072

Dhanekar, S. and S. Jain, 2013. Porous silicon biosensor: Current status. Biosensors Bioelectronics, 41: 54-64. DOI: $10.1016 /$ j.bios.2012.09.045

Ding, L., D. Du, X.J. Zhang and H.X. Ju, 2008. Trends in cell-based electrochemical biosensors. Current Medicinal Chemistry, 15: 3160-3170. DOI: $10.2174 / 092986708786848514$

Ekkhuntham, A., B. Jongsareejit, W. Yamkunthong and J. Wichitwechkarn, 2012. Purification and characterization of methyl parathion hydrolase from Burkholderia cepacia capable of degrading organophosphate insecticides. World J. Microbiology Biotechnol., 28: 1739-1746.

DOI: $10.1007 / \mathrm{s} 1$ 1274-011-0985-y

Ekkhuntham, A., J. Wichitwechkarn and W. Surareungchai, 2010. Development of biosensor for pesticide detection using methyl parathion hydrolase from recombinant MPD Clone. Proceedings of Pure and Applied Chemistry International Conference on "Challenges in Chemistry for Sustainable Development", Jan. 21-23, Ubonratchathani, Thailand, pp: 639-641.

FAO/WHO, 2018. Codex alimentarius international food standard. http://www.fao.org/fao-whocodexalimentarius/home/pt/

Gong, J., L. Wang and L. Zhang, 2009. Electrochemical biosensing of methyl parathion pesticide based on acetylcholinesterase immobilized onto $\mathrm{Au}$ polypyrrole interlaced network-like nanocomposite. Biosensors Bioelectronics, 24: 2285-2288.

DOI: 10.1016/j.bios.2008.11.012

Ji, X., J. Zheng, J. Xu, V.K. Rastogi and T.C. Cheng et al., 2005. (CdSe)ZnS quantum dots and organophosphorus hydrolase bioconjugate as biosensors for detection of paraoxon. J. Physical Chemistry B, 109: 3793-3799. DOI: $10.1021 / j p 044928 f$

Keprasertsup, C., S. Upatham, N. Sukhapanth and P. Prempree, 2001. Degradation of methyl parathion in an aqueous medium by soil bacteria. Sci. Asia, 27: 261-270. DOI: 10.2306/scienceasia.2001.27.261

Kumar, J. and S.F. D'Souza, 2010. An optical microbial biosensor for detection of methyl parathion using Sphingomonas sp. immobilized on microplate as a reusable biocomponent. Biosensors Bioelectronics, 26: 1292-1296. DOI: 10.1016/j.bios.2010.07.016
Kumar, J. and S.F. D'Souza, 2011. Microbial biosensor for detection of methyl parathion using screen printed carbon electrode and cyclic voltammetry. Biosensors Bioelectronics, 26: 4289-4293. DOI:10.1016/j.bios.2011.04.027

Kumar, S., G. Kaushik and J.F. Villarreal-Chiu, 2016. Scenario of organophosphate pollution and toxicity in India: A review. Environ. Sci. Pollution Res., 23: 9480-9491. DOI: 10.1007/s1 1356-016-6294-0

Laothanachareon, T., V. Champreda, P. Sritongkham, M. Somasundrum and W. Surareungchai, 2008. Crosslinked enzyme crystals of organophosphate hydrolase for electrochemical detection of organophosphorus compounds. World J. Microbiology Biotechnology, 24: 3049-3055.

DOI: $10.1007 / \mathrm{s} 11274-008-9851-y$

Lee, J.H., J.Y. Park, K. Min, H.J. Cha and S.S. Choi et al., 2010. A novel organophosphorus hydrolase-based biosensor using mesoporous carbons and carbon black for the detection of organophosphate nerve agents. Biosensors Bioelectronics, 25: 1566-1570. DOI: 10.1016/j.bios.2009.10.013

Lei, Y., W. Chen and A. Mulchandani, 2006. Microbial biosensors. Analytica Chimica Acta, 568: 200-210. DOI: 10.1016/j.aca.2005.11.065

Liu, G., W. Guo and Z. Yin, 2014. Covalent fabrication of methyl parathion hydrolase on gold nanoparticles modified carbon substrates for designing a methyl parathion biosensor. Biosensors Bioelectronics, 53: 440-446. DOI: 10.1016/j.bios.2013.10.025

Maxwell D.M., K.M. Brecht, I. Koplovitz and R.E. Sweeney, 2006. Acetylcholinesterase inhibition: dose it explain the toxicity of organophosphorus compounds? Archives Toxicology, 80: 756-760. DOI: $10.1007 / \mathrm{s} 00204-006-0120-2$

Mulchandani, A., P. Mulchandani, W. Chen, J. Wang and L. Chen, 1999. Amperometric thick-film strip electrodes for monitoring organophosphate nerve agents based on immobilized organophosphorus hydrolase. Analytical Chemistry, 71: 2246-2249. DOI: $10.1021 /$ ac9813179

Palchetti, I., A. Cagnini, M.D. Carlo, C. Coppi and M. Mascini et al., 1997. Determination of acetylcholinesterasepesticides in real sample using a disposable biosensor. Analytica Chimica Acta, 337: 315-321. DOI: 10.1016/S0003-2670(96)00418-7

Phillips, C.R. and Y.C. Poon, 1988. Immobilization of Cells. In: Methods of Cell Immobilization, Phillips, C.R. and Y.C. Poon, (Eds.), Springer, Berlin, Heidelberg, pp: 11-73, ISBN-10: 978-3-642-73251-5

Raghu, P., T.M. Reddy, B.E.K. Swamy, B.N. Chandrashekar and K. Reddaiah et al., 2012. Development of AChE biosensor for the determination of methyl parathion and monocrotophos in water and fruit samples: A cyclic voltammetric study. J. Electroanalytical Chemistry, 665: 76-82. DOI: $10.1016 /$ j.jelechem.2011.11.020 
Roger, K.R., C.J. Cao, J.J. Valdes, A.T. Eldefrawi and M.E. Eldefrawi, 1991. Acetylcholinesterase fiberoptic biosensor for detection of acetylcholinesterase. Fundamental Applied Toxicol., 16: 810-820. DOI: 10.1016/0272-0590(91)90166-2

Shing, W.L., L.Y. Heng and S. Surif, 2013. Performance of a cyanobacteria whole cell-based fluorescence biosensor for heavy metal and pesticide detection. Sensors, 13: 6394-6404. DOI: 10.3390/s130506394

Simonian, A.L., T.A. Good, S.S. Wang and J.R. Wild, 2005. Nanoparticle-based optical biosensors for the direct detection of organophosphate chemical warfare agent and pesticides. Analytica Chimica Acta, 534: 69-77. DOI: 10.1016/j.aca.2004.06.056

Su, L., W. Jia, C. Hou and Y. Lei, 2011. Microbial biosensors: A review. Biosensors Bioelectronics, 26: 1788-1799. DOI: 10.1016/j.bios.2010.09.005

Tang, X., T. Zhang, B. Liang, D. Han and L. Zeng et al., 2014. Sensitive electrochemical microbial biosensor for p-nitrophenyl organophosphates based on electrode modified with cell surface-displayed organophosphorus hydrolase and ordered mesopore carbons. Biosensors Bioelectronics, 60: 137-142. DOI: 10.1016/j.bios.2014.04.001

Watson, A., D. Opresko, R. Young, V. Hauschild and J. King et al., 2009. Organophosphate Nerve Agents. In: Handbook of Toxicology of Chemical Warfare Agents, Gupta, R.C., (Ed.), Academic Press, pp: 43-67, ISBN-10: 9780123744845
Xue, R., T.F. Kang, L.P. Lu and S.Y. Cheng, 2012. Immobilization of acetylcholinesterase via biocompatible interface of silk fibroin for detection of organophosphate and carbamate pesticides. Applied Surface Sci., 258: 6040-6045. DOI: 10.1016/j.apsusc.2012.02.123

Ye, H., Z. Guo, M. Peng, C. Cai and Y. Chen et al., 2016. Methyl parathion degrading enzyme-based nanohybrid biosensor for enhanced methyl parathion recognition. Electroanalysis, 28: 1591-1596. DOI: 10.1002/elan.201501102

Zhang, F. and J. Keasling, 2011. Biosensors and their applications in microbial metabolic engineering. Trends Microbiol., 19: 323-329.

DOI: 10.1016/j.tim.2011.05.003

Zhao, Y., W. Zhang, Y. Lin and D. Du, 2013. The vital function of Fe3O4@Au nanocomposites for Hydrolase biosensor design and its application in detection of methyl parathion. Nanoscale, 5: 1121-1126. DOI: $10.1039 / \mathrm{c} 2 \mathrm{nr} 33107 \mathrm{a}$

Zheng, Y., Z. Liu, Y. Jing, J. Li and H. Zhan, 2015. An acetylcholinesterase biosensor based on ionic liquid functionalized graphene-gelatin-modified electrode for sensitive detection of pesticides. Sensors Actuators B: Chemical, 210: 389-397.

DOI: $10.1016 /$ j.snb.2015.01.003 